\title{
Thromboangitis obliterans agyi manifesztációja
}

\author{
Aszalos Csongor ${ }^{1}$ - Dongó Eleni dr. ${ }^{2}$ - Farkas Zsuzsanna dr. ${ }^{2}$ \\ Kollár Attila dr. ${ }^{3}$ - Magyar Péter dr. ${ }^{3}$ - Várallyay György dr. ${ }^{4}$ \\ Bereczki Dániel dr. ${ }^{2}$ - Vastagh Ildikó dr. ${ }^{2}$
}

\author{
${ }^{1}$ Marosvásárhelyi Orvosi és Gyógyszerészeti Egyetem, Marosvásárhely \\ Semmelweis Egyetem, Általános Orvostudományi Kar, ${ }^{2}$ Neurológiai Klinika, \\ ${ }^{3}$ Radiológiai és Onkoterápiás Klinika, Budapest \\ ${ }^{4}$ Szentágothai János Tudásközpont, MR-kutatóközpont, Budapest
}

\begin{abstract}
A thromboangitis obliterans (Buerger-kór) nem atherosclerosisos, a kis- és közepes méretú artériák és vénák szegmentális gyulladásával és thromboticus elzáródásával járó perifériás érbetegség. Etiológiája a mai napig ismeretlen, szoros összefüggést mutat a dohányzással. A tünetek 45 éves kor előtt kezdődnek, jellegzetes a hullámzó kórlefolyás. A végtagok acralis részein akut és krónikus ischaemiás vagy infektív tünetek alakulnak ki. A Buerger-kór diagnózisa elsősorban a klinikai képen és az angiográfiás vizsgálaton alapul, de alapvetően fontos autoimmun betegség, thrombophilia, diabetes mellitus és proximalis emboliaforrás kizárása is. A betegség leggyakrabban a végtagok ereit érinti, ritkán azonban érintettek lehetnek az agyi, a coronaria- és a zsigeri artériák is. A szerzók 49 éves, korábban már Buerger-kór miatt kezelt férfi kórtörténetéról számolnak be, akinél akut ischaemiás stroke-ot diagnosztizáltak. Képalkotó vizsgálatokkal akut és krónikus ischaemiás laesiókat, valamint a tünetképző oldalon az arteria cerebri media nem atheroscleroticus arteriopathiáját igazolták. A részletes kivizsgálás során más etiológiát nem találtak. Orv. Hetil., 2016, 157(30), 1207-1211.
\end{abstract}

Kulcsszavak: thromboangitis obliterans, dohányzás, ischaemiás stroke

\section{Cerebral manifestations of thromboangiitis obliterans}

\section{Case report}

Thromboangiits obliterans (Buerger's disease) is a non-atherosclerotic, segmental inflammatory and obliterative disease affecting small and medium sized arteries and veins. The etiology is still unknown, but it is in close relationship with tobacco use. Symptoms begin under the age of 45 years and the undulating course is typical. Patients usually present with acute and chronic ischemic or infectious acral lesions. Diagnosis is usually based on clinical and angiographic criteria and it is important to exclude autoimmune disease, thrombophilia, diabetes, and proximal embolic sources. Even though Buerger's disease most commonly involves the arteries of the extremities, the pathologic findings sometimes affect the cerebral, coronary and internal thoracic, renal and mesenteric arteries as well. The authors present the history of a patient with known Buerger's disease and acute ischemic stroke. Brain imaging detected acute and chronic ischemic lesions caused by middle cerebral non-atherosclerotic arteriopathy on the symptomatic side. Other etiology was excluded by detailed investigations.

Keywords: thromboangiitis obliterans, tobacco use, ischemic stroke

Aszalos, Cs., Dongó, E., Farkas, Zs., Kollár, A., Magyar, P., Várallyay, Gy., Bereczki, D., Vastagh, I. [Cerebral manifestations of thromboangiitis obliterans. Case report]. Orv. Hetil., 2016, 157(30), 1207-1211.

(Beérkezett: 2016. március 19.; elfogadva: 2016. április 21.) 


\section{Rövidítések}

ACI $=$ arteria carotis interna; $\mathrm{ACM}=$ arteria cerebri media; DSA $=$ digitális szubtrakciós angiográfia $;$ TAG $=$ thrombocyta aggregáció-gátló; TAO = thromboangitis obliterans; TCCD = transcranialis color Doppler; TCD = transcranialis Doppler

A thromboangitis obliterans (TAO), szerzői néven Buerger-kór, a kis- és közepes méretû́ artériák és a felszínes vénák szegmentális gyulladásával és thromboticus elzáródásával járó, nem atherosclerosisos jellegú, krónikus perifériás érbetegség. Fóként a 45 évesnél fiatalabb, dohányzó férfiakat érinti [1]. A betegség elófordulása földrészenként különböző. Az európai lakosság körében az összes perifériás érbetegség 0,5-6,5\%-a Buerger-kór, Indiában ez 45-63\%, az askenázi zsidók körében már 80\% a gyakorisága [2]. A férfiak és nők közötti előfordulási arány $14: 1$. Az Európában élő 45 évesnél fiatalabb dohányzó férfiak körében a Buerger-kór incidenciája évente 12 eset/100 000 lakos [3]. A TAO etiológiája jelenleg ismeretlen. A betegség előfordulása szorosan összefügg a dohányzással [4].

A Buerger-kór eseteinek mindössze $2 \%$-a érinti az agyi ereket $[5,6]$. Az agyi ereket érintő TAO-nak két különböző neuropatológiai formája ismert. Az egyik az $1 \mathrm{~mm}$ nél kisebb átmérójü agyi ereken okoz elváltozásokat. A másik formában az arteria carotis interna (ACI) vagy az arteria cerebri media (ACM) thrombosisa a distalis kiserek érintettségével kombináltan jelentkezik [5, 7].

Közleményünkben fiatal férfi esetét mutatjuk be, akinél a képalkotó vizsgálatokkal igazolt többszakaszos ischaemiás stroke hátterében Buerger-kór agyi manifesztációja igazolódott.

\section{Esetismertetés}

A 49 éves férfit egy napja tartó beszédzavar miatt vettük fel a Semmelweis Egyetem Neurológiai Klinikájára. A heteroanamnézis szerint a felvételét megelőző napokban nem ismerte meg közvetlen munkatársait. A beteg 20 éves kora óta dohányzott. A dohányzást 45 éves korában abbahagyta, de jelen felvétele előtt fél évvel újra elkezdte.

Negyvennégy éves korában a bal alsó végtag I-III. ujjainak fájdalommal kísért livid elszíneződése miatt érsebészeti vizsgálat történt, microembolisatiót feltételeztek. Holter-vizsgálat és a hasi aorta ultrahangvizsgálata emboliaforrást nem igazolt. Vérzsírszintjei a normáltartományban voltak, normális éhomi vércukorértékei alapján diabetes mellitus nem merült fel. Fokozott thrombosishajlam irányába végzett részletes laboratóriumi vizsgálatok (szérumfibrinogén, D-dimer, kardiolipin-antitest, lupus anticoagulans, béta-2-GPI antitest, protein C- és protein S-aktivitás, plazminogén, von-Willebrand-faktor, FVIII-aktivitás, Leiden-mutáció, protrombinG20210A-mutáció) kismértékben csökkent antitrombin-III-aktivitáson kívül kórosat nem találtak. Egy évvel később megismételt kontrollvizsgálatakor az antitrom-
bin-III-aktivitás már a normáltartományban volt. Angiológiai javaslatra parenteralisan pentoxifyllint kapott, panaszai mérséklődtek. Korábbi panaszai mellett 45 éves korában a bal alsó végtag III. ujján hámhiány is kialakult. DSA- (digitális szubtrakciós angiográfia) vizsgálat a bal oldali arteria femoralis superficialis distalis harmadában $0,5 \mathrm{~cm}$ hosszú szakaszon 75\%-os szúkületet (1.A) ábra), az arteria poplitea kezdeti szakaszán egy rövid, 75\%-os szúkületet talált (1. B) ábra). Jobb oldalon az arteria poplitea középső harmadában egy $50 \%$-os stenosist okozó egyenetlenül szúkebb szakaszt, a tibioperonealis törzs kezdetén $60 \%$-os szúkületet ábrázolt. Az alsó végtagi nagyerekben atheroscleroticus eltérés nem látszott. Ezek alapján Buerger-kór lehetősége merült fel. Ezt követően a bal oldali arteria femoralis superficialis stentelését és a bal oldali arteria poplitea stenosis angioplasztikáját végezték el. Azóta a beteg naponta $100 \mathrm{mg}$ acetilszalicilsavat és $50 \mathrm{mg}$ pentosan-poliszulfátot szedett. Jelen felvételét megelőző utolsó, egy évvel ezelőtt történt alsó végtagi ultrahangvizsgálat a korábbi elváltozások mellett bal oldalon az arteria dorsalis pedis, jobb oldalon az arteria tibialis posterior occlusióját igazolta.

Jelen felvételekor fizikális vizsgálattal jobb oldalon centrális facialis paresist, felső végtagi túlsúlyú enyhe fokú hemiparesist, Hoffmann- és Trömner-jelet, valamint enyhe fokú szenzoros túlsúlyú kevert afáziát találtunk. Az arteria tibialis posterior és az arteria dorsalis pedis pulzusát egyik oldalon sem lehetett tapintani. A felvételkor elvégzett natív koponya-CT-vizsgálat a bal hemispheriumban a hátsó határzónában és a gyrus praecentralis előtt corticalisan és subcorticalisan krónikus ischaemiás laesióra jellemző hipodenzitásokat ábrázolt,

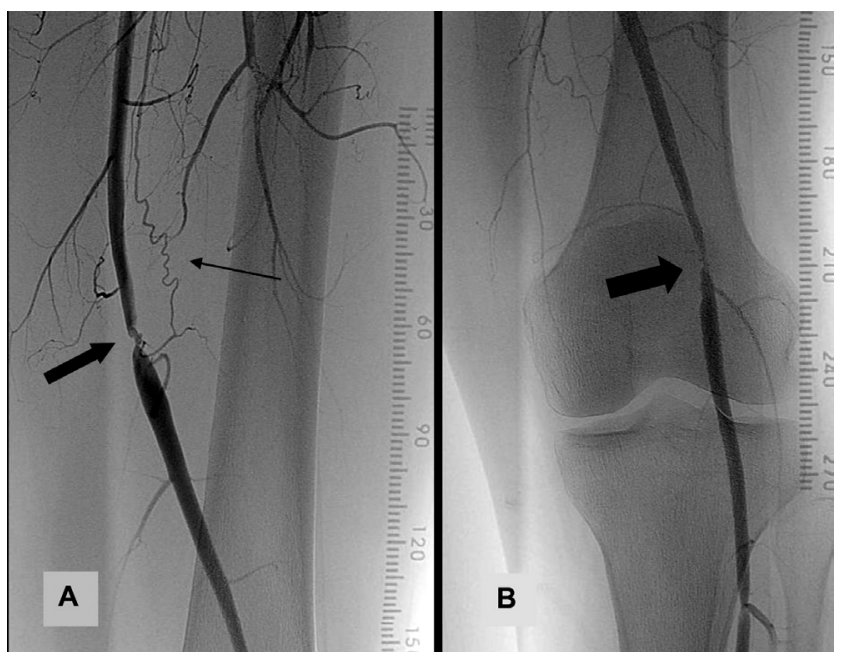

\begin{tabular}{l|l} 
1. ábra & A) A beteg 45 éves korában végzett angiográfiás vizsgálat a bal
\end{tabular} oldali arteria femoralis superficialis distalis harmadában $0,5 \mathrm{~cm}$ hosszú szakaszon $75 \%$-os szúkületet detektált (vastag nyíl). A vékony nyíl a kanyargós, „dugóhúzó formájú” collateralisra mutat. B) A vastag nyíl a bal oldali arteria poplitea kezdeti szakaszán lévő rövid, 75\%-os szúkületre mutat. Mindkét ábrán az erek a szegmentális, rövid szakaszú szúkületek kivételével sima felszínúek, hiányoznak a típusos arterioscleroticus eltérések. A vizsgálat Philips Allure XPER készülékkel történt 
a tüneteket magyarázó akut eltérés nem látszott. Ezt követően agyi MR-vizsgálat készült, amely a bal oldali nucleus caudatust, a bal frontotemporalis régiót érintő kiterjedt multiplex friss agyi infarktusokat igazolt (2. $A)-B$ ) ábra). Az extra- és intracranialis erek CT-angiográfiája a carotis és a vertebralis rendszerben atheroscleroticus eltéréseket nem talált. A bal oldali ACM Ml-es szakaszán $2 \mathrm{~cm}$ hosszan éles kontúrú gracilis telődés ábrázolódott atheroscleroticus eltérések nélkül (2. C) ábra). A carotisok duplex ultrahangvizsgálatával ép falszerkezetet találtunk (2. D) ábra), a bal oldali ACI-ban az áramlási sebesség deprimált (ellenoldali érték kétharmada) volt, amely distalisabban lévő stenosisra utal. Transcranialis Doppler- és color Doppler- (TCD és TCCD) vizsgálat a bal oldali ACM Ml-es szakaszán ( 58 mm-es mélységben) rövid szakaszon gyorsult $\left(\mathrm{v}_{\max }: 189 / 65 \mathrm{~cm} / \mathrm{s} ; \mathrm{v}_{\text {mean }}\right.$ :

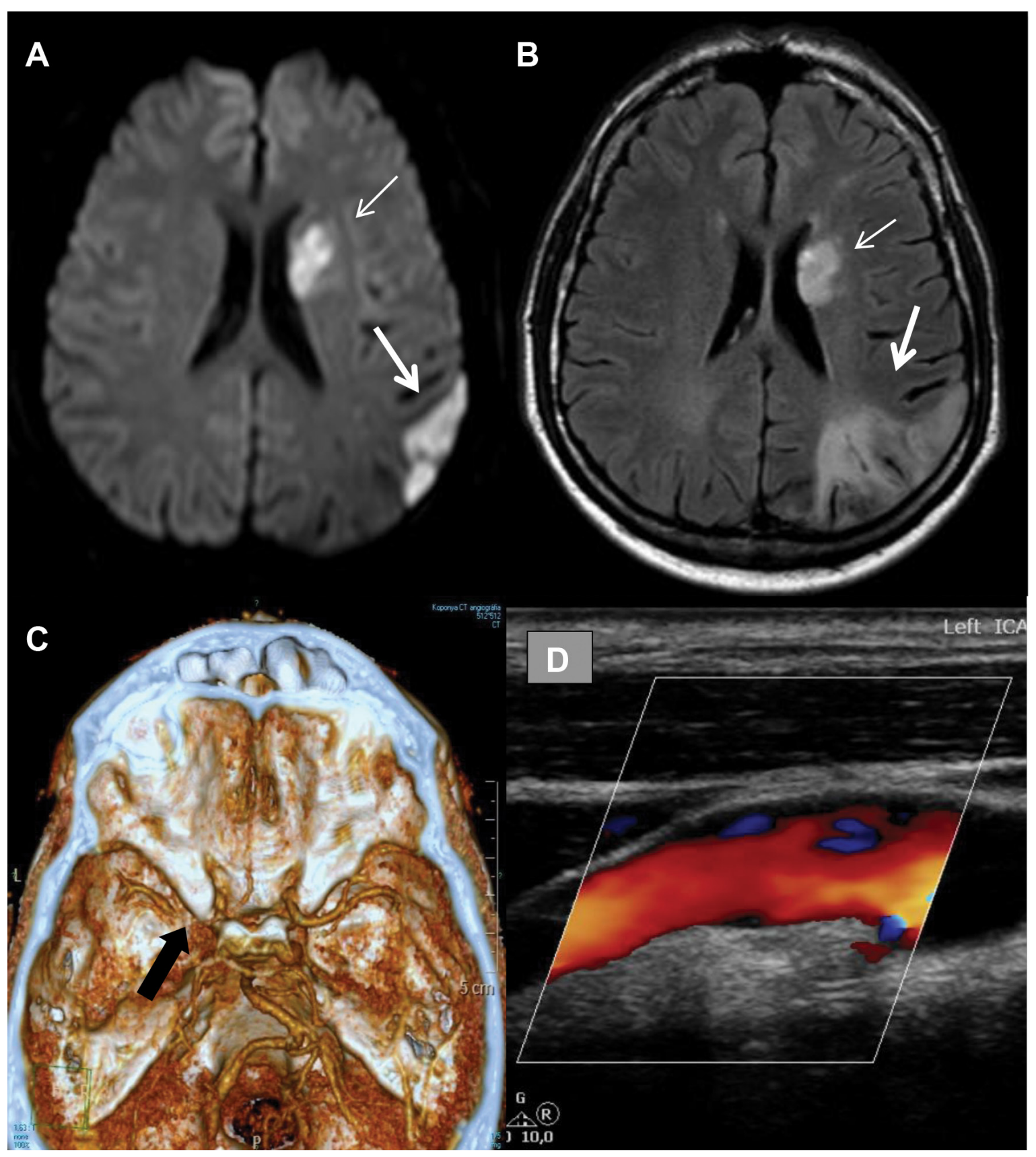

2. ábra

A) A diffúziósúlyozású MR-felvételen a bal féltekében temporalisan ék alakú (vastag nyíl) és az oldalkamra melletti fehérállományban (vékony nyíl) is gátolt diffúzió látszik, amely friss infarktusra utal. B) Az előbbi lokalizációban, de nagyobb kiterjedésű jelfokozódás látszik a FLAIR-képen, amely régebbi infarktusnak felel meg. C) A CT-angiográfiás sorozat volume-rendered 3D rekonstrukciós képén a vertex felől tekintünk a középső scalába (az egyezményes láb felóli nézet helyett), ezért a kép bal oldala a páciens bal oldalának felel meg. A nyíl a bal oldali ACM Ml-es szakaszán lévő, körülbelül $2 \mathrm{~cm}$ hosszú gracilis telődésre mutat. Ezen a szakaszon kóros meszesedés nem látszott. A többi érterületben és a bal ACM további szakaszain is szabályos érkaliber ábrázolódik. D) A bal ACI bulbusa látható, amelyben az intima ép, az áramlás fiziológiás. Az MR-vizsgálatok Philips 3 T-ás, a komputertomográfás vizsgálat Philips Brilliance 16 szeletes CT-vel, az ultrahangos vizsgálat Philips HD 15.0 készülékkel (L 12-3 transzducer) történt 
$115 \mathrm{~cm} / \mathrm{s}$ ) és kissé turbulens áramlást detektált, ami körülírt, közepesen súlyos stenosisra utal. Kardiogén emboliaforrás kizárása céljából elvégzett transthoracalis szív-ultrahangvizsgálat morfológiai és funkcionális eltérést nem igazolt. Agitált só-levegő kontrasztos TCDvizsgálattal intracardialis jobb-bal söntre jellemző eltérést nem találtunk. Holter-monitorozás során ritmuszavar nem jelentkezett. Az alsó végtagok artériáinak kontroll duplex UH-vizsgálata Buerger-kórnak megfelelő állapotot jelzett. Enyhén emelkedett szérumhomocisztein(Hcy-) szintet találtunk $(17,5 \mu \mathrm{mol} / \mathrm{L}$, normáltartomány 5,4-16,0 $\mu \mathrm{mol} / \mathrm{L})$. A vizsgált egyéb laboratóriumi paraméterek (vérkép, protrombinidő, INR, APTI, D-dimer, glükóz, összbilirubin, BUN, kreatinin, GFR, LDH, GOT, GPT, gamma-GT, nátrium, kálium, kalcium, klorid, CRP, alkalikus foszfatáz, triglicerid, összkoleszterin, HDL- és LDL-koleszterin, húgysav) a normális tartományban voltak. A lumbalisan vett liquor cerebrospinalisban az összfehérje-koncentráció 0,68 g/L, a sejtszám 1 lymphocyta $/ \mathrm{mm}^{3}$ volt. Angiitist a szerológiai vizsgálatokkal nem tudtunk igazolni (szérum autoimmun panel, szérum és liquor Borrelia IgG és IgM, szérum és liquor Treponema pallidum-antitest, HIV-szerológia). Kettős thrombocytaaggregáció-gátló kezelést (75 mg clopidogrel +100 mg acetilszalicilsav) kezdtünk. A kismértékben magas szérum-Hcy-szint miatt folsav szedését javasoltuk. Egy hét múlva paresise megszűnt, afáziája is jelentősen javult. A bal ACM közepesen súlyos szúkületének a rekonstrukcióját intervenciós radiológiai és idegsebészeti konzílium sem javasolta.

Fél évvel később neurológiai állapota nem változott, enyhe fokú afáziát találtunk. Az extracranialis artériák color duplex ultrahangvizsgálata továbbra is ép érrendszert igazolt. A TCD- és TCCD-vizsgálat csak a már korábban is leírt bal ACM $\mathrm{Ml}$-es részén detektált rövid szakaszra kiterjedő közepesen súlyos stenosist. A beteg napi 75 mg clopidogrel-monoterápiát kap.

\section{Megbeszélés}

A thromboangitis obliterans két alapvető jellegzetessége, hogy a betegség a végtagok kis- és középnagy artériáit és vénáit érinti, valamint hogy exacerbatiók és hosszú remissziók váltják egymást [8]. A végtagok distalis részén fájdalmas fekélyek és gangraenák alakulnak ki. A betegség progressziója során gyakran jelentkezik Raynaud-jelenség a felső végtag ujjain. A TAO oka jelenleg nem ismert, de szoros összefüggést mutat a dohányzással. Ennek abbahagyása a betegség progresszióját nagymértékben lassítja, ismételt elkezdése azonban fellángolásokhoz vezethet [4]. A különböző földrajzi régiók és etnikumok között a prevalencia jelentősen különbözik, ez alapján felmerül genetikai háttér lehetősége is [2]. Hyperhomocysteineamia (HHcy) előfordulása gyakori Buerger-kórban $[9,10]$. Ismert, hogy a HHcy különböző cardiovascularis betegségek független rizikófaktora, amit elsősorban a Hcy endothelkárosító hatásával ma- gyaráznak. Újabb kutatások alapján a Hcy az endoplasmaticus reticulum stressz mediálta ioncsatorna-gátlásával okoz endotheliumdiszfunkciót [11]. Betegünkben a Hcy kissé emelkedett volt. A HLA-DR3 haplotípus előfordulása szignifikánsan gyakoribb Buerger-kóros betegekben, ami autoimmun mechanizmus szerepére utalhat [12]. Az atherosclerosis patogeneziséhez hasonlóan Buerger-kórban is felmerült a krónikus gyulladásos folyamatok jelentősége. Érdekesség, hogy periodontalis fertőzéseknek is jelentőséget tulajdonítanak [13].

A betegségre jellemző morfológiai elváltozások kialakulásának két szakasza ismert. Kezdetben friss thrombusok zárják el az artériák, ritkábban a vénák lumenét. Ezután az intimában gyulladásos folyamat indul el, endothelialis sejtburjánzás és lymphocytás beszưrődés alakul ki, ami fibrinoid necrosishoz vezet. A késői szakaszban a szervült thrombus recanalisatiója és perivascularis fibrosis zajlik [5]

Az agyi ereket érintő TAO-nak két különböző patológiai formája ismert. Az egyik az 1 mm-nél kisebb átmérőjú agyi ereken okoz elváltozásokat. A másik formában az ACI vagy az ACM thrombosisa a distalis kiserek érintettségével kombináltan jelentkezik $[5,7,14]$. A neurológiai kép nem különbözik az egyéb eredetű agyi keringészavarokban jelentkező tünetektől. Az ischaemia következtében góctünetek alakulhatnak ki (paresisek, látótérkiesések, afázia, dysarthria, cerebellaris tünetek stb.). Ha az arteria carotis externa ágrendszere is érintett, a szájüregben fekélyek jelenhetnek meg [5].

A Buerger-kór diagnosztikai kritériumai a következők: 45 éves kor előtt jelentkező ischaemiás tünetek a végtagok distalis területein; az alsó végtagon az arteria popliteától, a felső végtagon az arteria brachialis distalis szakaszától proximalisan levő erek épsége; arteriográfiával igazolt elzáródások a végtagok distalis ereiben. Kizáró kritérium a proximalis emboliaforrás, trauma, autoimmun betegség, diabetes, hyperlipidaemia jelenléte [5]. Esetünkben differenciáldiagnosztikai problémát az arteria femoralis superficialis érintettsége okozott, azonban ezen a szakaszon sem ábrázolódott atheroscleroticus elváltozás, az elzáródás radiomorfológiai képe nincs ellentmondásban a TAO-ban látott eltérésekkel.

A betegség kezelésében a legfontosabb tényező a dohányzás abbahagyása, amely a betegség progresszióját a legtöbb esetben megállítja, időnként az érfalkárosodás regressziójáról is beszámoltak $[5,15]$. Betegünk példája is ezt támasztja alá, mivel a dohányzás abbahagyása után az alsó végtagi betegsége nem romlott, viszont a dohányzás újrakezdését követően jelentkezett az agyi manifesztáció. Az irodalomban szélsőséges esetekről is beszámolnak. Bischof és mtsai azt találták, hogy hosszabb dohányzásmentes időszak után párórás cigarettázás is kiválthatja a betegség akut fellángolását [4]. Betegünkben három és fél éves dohányzásmentes periódus után fél éves dohányzást követően alakult ki az újabb exacerbatio. Thrombocytaaggregáció-gátló (TAG-) kezelés védelmet nyújthat a thromboticus szövődmények kialaku- 
lása ellen, azonban hosszú távú hatása nem bizonyított [2]. A pentoxifyllint gyakran alkalmazzák a betegség alsó végtagi manifesztációjában, azonban egyértelmü klinikai bizonyítékok nem támasztják alá a hatásosságát [16]. Cyclophosphamiddal és más immunszuppresszív szerekkel történt terápiás kísérletekről egyelőre kevés adat áll rendelkezésre ahhoz, hogy ezek hatékonyságáról következtetéseket tudjunk levonni [2]. Az utóbbi három évben végzett metaanalízisek, amelyek az őssejtek terápiás hatását vizsgálták Buerger-kórban, pozitív eredményekről számoltak be, mind a sebgyógyulás, mind a végtag-amputáció megelőzése tekintetében [17]. A revascularisatiós módszerek az esetek többségében nem alkalmazhatók [2]. A társuló HHcy kezelésére folsav adása ajánlott [9].

\section{Következtetés}

A fiatal életkorban bekövetkező ischaemiás stroke a legtöbb esetben differenciáldiagnosztikai nehézséget jelent. Az afáziás betegnél a képalkotó vizsgálatok többlépcsős ischaemiás laesiókat igazoltak, azonban a betegnek a dohányzás kivételével nem volt más cardiovascularis rizikófaktora. A beteg kórelőzményében szereplő alsó végtagi Buerger-kór irányította a figyelmünket annak a cerebralis ereket is érintő formájára. A cerebralis TAO diagnózisához a meglévő kórelőzményi adatok ismerete mellett részletes átvizsgálásra van szükség. A diagnosztikai kritériumok alapján cardioembolisatiót, autoimmun betegséget, trombophiliát, érmalformációt kell kizárni. Az intraés extracranialis agyi artériák CT-MR angiográfiás vizsgálata, a részletes neuroszonológiai vizsgálat igazolta az extracranialis artériák épségét, valamint a tünetképző oldalon az arteria cerebri media nem atheroscleroticus arteriopathiáját. Az agyi MR-vizsgálattal kimutatott határzóna-infarktus kialakulásában a kiserek érintettségének is szerepe lehetett. A cerebralis TAO kezelésében is legfontosabb a dohányzás abbahagyása, másodlagos prevencióként thrombocytaaggregáció-gátló szedése javasolt.

Anyagi támogatás: A közlemény megírása anyagi támogatásban nem részesült.

Szerzôi munkamegosztás: A. Cs., D. E., F. Zs., B. D., V. I.: A vizsgálatok lefolytatása, a kézirat megszövegezése. K. A., M. P., V. Gy.: Képalkotó vizsgálatok. A cikk végleges változatát valamennyi szerző elolvasta és jóváhagyta.

Érdekeltségek: A szerzőknek nincsenek érdekeltségeik.

\section{Irodalom}

[1] Fazeli, B., Ravari, H.: Mechanisms of thrombosis, available treatments and management challenges presented by thromboangiitis obliterans. Curr. Med. Chem., 2015, 22(16), 19922001.

[2] Klein-Weigel, P. F., Richter, J. G.: Thromboangiitis obliterans (Buerger's disease). Vasa, 2014, 43(5), 337-350.

[3] Jiménez-Paredes, C. A., Cañas-Dávila, C. A., Sanchez, A., et al.: Buerger's disease at the 'San Juan De Dios' Hospital, Santa Fe De Bogota, Colombia. Int. J. Cardiol., 1998, 66(Suppl. 1), S267-S272.

[4] Bischof, F., Kuntz, R., Melms, A., et al.: Cerebral vein thrombosis in a case with thromboangiitis obliterans. Cerebrovasc. Dis., 1999, 9(5), 295-297.

[5] Caplan, L. R., Bogousslavsky, J.: Uncommon causes of stroke. 2nd edition. Cambridge University Press, 2008.

[6] No, Y.J., Lee, E. M., Lee, D. H., et al.: Cerebral angiographic findings in thromboangiitis obliterans. Neuroradiology, 2005, $47(12), 912-915$.

[7] Fisher, C. M.: Cerebral thromboangiitis obliterans. Medicine (Baltimore), 1957, 36(2), 169-209.

[8] Pécsvárady, Zs.: Buerger's disease. [A Buerger-kór.] Hippocrates, 1999, I(2), 93-94. [Hungarian]

[9] Beigi, A. A., Hoghoughi, M. A., Eshaghian, A., et al.: The role of folic acid on the hyperhomocysteinemia in the Buerger's disease (thromboangiitis obliterans). J. Res. Med. Sci., 2014, 19(11), 1034-1037.

[10] Calgüneri, M., Oztürk, M. A., Ay, H., et al.: Buerger's disease with multisystem involvement. A case report and a review of the literature. Angiology, 2004, 55(3), 325-328.

[11] Wang, X. C., Sun, W. T., Yu, C. M., et al.: ER stress mediates homocysteine-induced endothelial dysfunction: Modulation of $\mathrm{IK}_{\mathrm{Ca}}$ and $\mathrm{SK}_{\mathrm{Ca}}$ channels. Atherosclerosis, 2015, 242(1), 191198.

[12] Kobayashi, M., Sugimoto, M., Komori, K.: Endarteritis obliterans in the pathogenesis of Buerger's disease from the pathological and immunohistochemical points of view. Circ. J., 2014, 78(12), 2819-2826.

[13] Pavlic, V., Vujic-Aleksic, V., Zubovic, N., et al.: Periodontitis and Buerger's disease: recent advences. Acta Inform. Med., 2013, 21(4), 250-252.

[14] Zülch, K. J., Pilz, P.: Thromboangiitis obliterans (von Winiwarter-Buerger). In: Toole, J. F. (ed.): Handbook of clinical neurology. Elsevier Science Publishers, Amsterdam, 1989.

[15] Liew, N. C., Lee, L., Nor, H. Z., et al.: Pathogenesis and management of Buerger's disease. Int. J. Low Extrem Wounds, 2015 , 14(3), 231-235.

[16] Diehm, C., Schäfer, M.: The Buerger's disease (thromboangiitis obliterans). History, epidemiology, pathology, clinical aspects, diagnostics and therapy. [Das Buerger-Syndrom (Thrombangiitis Obliterans). Geschichte, Epidemiologie, Pathologie, Klinik, Diagnostik und Therapie.] Springer Verlag, Berlin, Heidelberg, New York, 1993. [German]

[17] Boda, Z., Udvardy, M., Rázsó, K., et al.: Stem cell therapy: a promising and prospective approach in the treatment of patients with severe Buerger's disease. Clin. Appl. Thromb. Hemost., $2009,15(5), 552-560$

(Vastagh Ildikó dr., Budapest, Balassa u. 6., 1083 e-mail: vastagh.ildiko@med.semmelweis-univ.hu) 